Piotr Domeracki*

ORCID: 0000-0003-1339-9500

Toruń, Poland

\title{
Three Rival Versions of a Correlation Between Solitude and Communitiveness in a Monoseological Discourse
}

\author{
Trzy konkurencyjne warianty \\ korelacji samotności i wspólnotowości \\ w dyskursie monoseologicznym
}

\begin{abstract}
As the title states, this article focuses on a controversial topic: the lack of satisfactory solutions to the problem of the limits of the phenomena of solitude and communitiveness. It is based on the idea that monoseological discourse is intrinsic to this discourse. The term 'monoseology' is derived from two combined ancient Greek words: 'monosé', which means 'solitude'; and 'logos', translated etymologically as 'a rational, critical thinking', and more specifically as 'a science', 'a theory'. Hence, monoseology, in its wider meaning, is used to designate all sciences interested in analysing and conducting systematic research on solitude; in a narrower sense, the term 'monoseology' means simply the philosophy of solitude. It is quite commonly agreed that solitude in itself only consists of negative aspects, but communitiveness on the contrary has only positive ones. Therefore, solitude deserves clear and firm criticism, while communitiveness is assessed in a univocally positive way. This, in turn, translates to an unquestioning preference for ideas,

* Piotr Domeracki, Ph.D., Assistant Professor, Faculty of Philosophy and Social Sciences, Institute of Philosophy, Nicolaus Copernicus University in Toruń, email: domp@umk.pl.
\end{abstract}


feelings, motives and acts which are of community character and use. On the other hand, loneliness is recognised as a reason for our pain, suffering, fears, sadness and horrible despair. The result is the assumption that our key ambition, need and aim is to avoid and prevent each form of loneliness in our private and social life, at all costs. However, this causes many further problems - not only theoretical, but unfortunately also practical - which some researchers and ordinary people must face. This kind of unilateral and unambiguous interpretation of both solitude and communitiveness is called in the article 'monolectical'. In addition, it is shown here that the 'monolectics' of communitiveness or solitude is insufficient to provide an objective and complete picture of the two. In consequence, it is argued that monoseological discourse can succeed and develop itself only by turning to the dialectical method of explaining. The fundamental thesis and belief of this approach, expressed based on the dialectic of solitude and communitiveness, is that solitude and communitiveness are not at all isolated but strongly complementary. A practical conclusion arises from this statement: that each of us should intertwine in his or her life some periods of communitiveness and then some episodes of solitude.

Keywords: solitude; communitiveness; philosophy of solitude; monoseology; vita separata; vita mixta; vita paradoxa.

Streszczenie: W moim przedłożeniu koncentruję się na budzącym kontrowersje, złożonym i zróżnicowanym problemie granic fenomenu samotności i wspólnotowości. Rozpatruję go na gruncie dyskursu monoseologicznego. W szerszym rozumieniu termin monoseologia odnosi się do wszystkich nauk zainteresowanych analizą oraz systematycznymi badaniami nad samotnością; w węższym znaczeniu termin ten oznacza filozofię samotności. Istnieje dosyć powszechne przekonanie, że samotność posiada jedynie złe strony, wspólnotowość zaś przeciwnie, wyłącznie dobre. To z kolei przekłada się na preferowanie uczuć, motywów oraz czynów, które mają charakter wspólnotowy lub wspólnototwórczy. Można wręcz mówić o swego rodzaju fetyszyzacji wspólnotowości i wspólnotowych form życia. Samotność postrzegana jako kontradyktoryczna wobec wspólnoty forma życia, uznawana za jej [tej wspólnoty] negację, zagrożenie i zwyrodnienie (degenerację), jest przeto nader jednostronnie, tendencyjnie i płasko - identyfikowana jako jeden z podstawowych predyktorów, a równocześnie jeden z najbardziej niebezpiecznych czynników ryzyka odpowiadających za powstanie, stymulowanie, utrwalanie bądź pogłębianie różnego rodzaju deficytów, patologii i anomalii w obszarze ludzkiej egzystencji (które w ogólności można określić mianem stanów patoegzystencjalnych, takich na przykład, jak cierpienie, lęk, smutek, tęsknota, nostalgia, rozpacz, apatia, depresja, etc.). Na tej podstawie wyprowadzany jest cokolwiek podejrzany - by nie powie- 
dzieć fałszywy - wniosek, że podstawowym zadaniem każdego człowieka jest taka organizacja systemu życia (zarówno indywidualnego, jak i społecznego), która wyklucza, eliminuje bądź zapobiega wszelkim przejawom samotności. Tego rodzaju upraszczające i jednostronne podejście do zagadnienia nazywam monolektycznym. W swoim artykule zamierzam wykazać, że ta głęboko zakorzeniona w filozofii, etyce i kulturze łacińskiej monolektyczna wykładnia i aksjologia samotności i wspólnotowości jest nie tylko wątpliwa poznawczo i niewystarczająca eksplanacyjnie, ale nadto, że domaga się ona znaczącej korekty (co odnosi się także do konieczności przeformułowania istniejącego od czasów greckiej $\pi$ ó $\lambda 1 \varsigma$ paradygmatu kulturowego oraz strategii edukacyjnych i oddziaływań wychowawczych w kluczu edukacji do samotności). W związku z tym przedstawiam argumenty i racje obligujące do zastąpienia w dyskursie monoseologicznym (samotnościowym) narracji monolektycznej - dialektyczną. Zabieg ten, w zamyśle, pozwoli uzyskać możliwie pełny, sensowny i bardziej adekwatny obraz obu tych, traktowanych jako komplementarne, fenomenów - samotności i wspólnotowości. Podstawową tezą, jakiej zamierzam bronić, jest stwierdzenie, że samotność i wspólnotowość, rozpatrywane w porządku dialektycznym, nie występują w separacji, lecz w istotny sposób wzajemnie się warunkują i dopełniają. Stwierdzenie to prowadzi do praktycznej w swej wymowie konkluzji, że każdy z nas może i powinien radzić sobie z wyzwaniami samotności oraz bycia we wspólnocie, przeplatając i łącząc w swoim życiu periody wspólnotowości z równie inspirującymi epizodami samotności.

Słowa kluczowe: samotność; wspólnotowość; filozofia samotności; monoseologia; vita separata; vita mixta; vita paradoxa.

Nevertheless we ought to mix up these two things, and to pass our lives alternately in solitude and among throngs of people. (Seneca, 1989, pp. 661-662)

Loneliness always presupposes the need of community, longing for community. (Berdyaev, 2002, p. 54)

\section{Vita separata: The dissonance between solitude and communitiveness}

During the history and development of Western philosophy, various schools, currents, directions, concepts and positions, have led (although rel- 
atively late) to the emergence of a discourse which I call 'monoseological'. ${ }^{1}$ It is a part of and contributes to the philosophy of solitude - a field which was called so as late as in the 20th century by Nikolai Berdyaev (2002) and Emmanuel Lévinas (1999), who independently coined this expression. The differentia specifica of monoseological discourse is, as indicated by its very name, the thematisation and articulation of the phenomenon of solitude in the aspect of the ontological, functional and conceptual 'density' (to use Ricoeur's term [1989, p. 224]) of the reality that it constitutes.

Of course, monoseological discourse extends beyond the area of philosophy alone, into multiple disciplines of knowledge. ${ }^{2}$ In recent years it seems to have experienced a dynamic growth, also outside science. This is evidenced, for instance, by the significant and constantly growing number of publications, starting with articles appearing in periodicals ${ }^{3}$ (in particular, popular science and opinion-forming ones) and ending with serious scientific dissertations (Howard, 1975; Lynch, 1977, 1985, 2000; Mijuskovic, 2012, 2015, 2019; Moustakas, 1961, 1972, 1974, 1975; McGraw, 2010, 2012; Hojat \& Crandall, 1987; Peplau, Perlman, 1982; Stern, 2012; Turkle, 2013; Cacioppo \& Patrick, 2008; Kmiecik-Baran, 1988, 1992, 1993; Dołęga, 2003; Dubas, 2000; Domeracki \& Tyburski, 2006; Domeracki, 2016, 2018; Dybeł, 2009; Pawłowska \& Jundziłł, 2000, 2006; Twardowska-Rajewska, 2005; Szeliga \& Żółkiewska, 2010; Mółka, 2012; Sobstyl, 2013; Kuklińska, 2013; Grzybek, 2013).

In recent years, the particular strand of thought concerning the problem of community and community-forming aspirations, which I refer to as 'communitiveness', has been developing in an increasingly expansive way. In terms of the 20th century, we may even speak of an explosion of interest in such phenomena. It is enough to mention the various directions of thinking, such as socialism, communitarianism, discoursivism, philosophy of dialogue, or personalism. Also, in the past years of the present century,

1 The term 'monoseology' I derive from the old Greek language, from the words 'monosé' ('solitude') and 'logos' ('science'). I use this term to refer in general to all scientific disciplines interested in analysing and conducting systematic research on solitude in an interdisciplinary manner. More narrowly, I utilise the term 'monoseology' to refer only to the 'philosophy of solitude', and I treat both expressions as synonyms.

2 Among them, is it first necessary to enumerate psychology, sociology, pedagogy, ethnology and theology.

${ }^{3}$ As examples I can mention such Polish journals as Charaktery, Przeglad, Wysokie Obcasy Extra, Jesuit Szum z Nieba. 
a tendency to scientifically elaborate on the issue of communitiveness and community (Sierocka, 2007) was retained, increasingly often manifesting itself in individual, albeit important, approaches. For example, we should mention at least the works by Helmuth Plessner (2008) and Zygmunt Bauman (2008).

In terms of importance, although the subject of solitude began to gain significance from the second half of the 20th century onwards, gradually becoming autonomous, it was understandably unable to match, and even less so to outstrip, the level of interest in and advancement of research on the phenomenon of communitiveness. Many authors point to and emphasise the central, dominant position of this problem; not only in the field of philosophy, but also in the humanities and social sciences in general. Some even speak of an obsession with communitiveness. For instance, Plessner (2008, p. 27) unceremoniously states that the community has become the 'idol of this age':

The idol of community exercises its fascination on the weak: it is to be understood as the ideology of the excluded, the disappointed, and the stalling of the proletariat, of the impoverished and of youth, a generation that has only just become aware of the chains that bind it; it is justified as the protest of those suffering under the modern metropolis, the machine age and social uprootedness. Under its motto entire armies came into being and thousands of people were ready to die. (ibidem, p. 28)

And later, slightly ironically, Plessner notes:

As compensation for the hardness and staleness of our life, this idea [of community] has compressed all sweetness into mawkishness, tenderness into weakness, and flexibility into the loss of dignity. ... An immeasurable chilling of human relationships by mechanical, commercial, and political abstractions conditions an immeasurable reaction in the ideal of a shimmering community overflowing through all of its supporters. Calculation and brutal pursuit of business is countered with the image of happiness arising from spontaneous self-giving, distrustful division into armoured states - the world alliance of nations to establish eternal peace. (ibidem, p. 27)

Plessner (ibidem, p. 27) derives from this an extremely important conclusion for our deliberations. Namely, he states that 'for this reason the law of distance no longer applies, loneliness has lost its charm’. 
Similarly to Plessner, Zygmunt Bauman also points out the 'sweetness' of community turning into 'sentimentality', by saying:

The 'community' sounds good: whatever it means, it is good to 'have a community', to 'be in a community'. ... Companionship or a society may be bad; but not a community. We have a sense that community is always something good. (Bauman, 2008, p. 5)

The late lamented Anthony Storr (died in 2001), an English psychiatrist and writer, in his excellent book from 1988 entitled Solitude: a Return to the Self, which has only recently been published in Poland (2010), repeatedly indicates that a conviction - by no means a new one, if I may add a side note emerged in the general consciousness of people. John Bowlby is the most outstanding mouthpiece for this conviction in the field of psychoanalysis, which is the closest to Storr's profession; he expresses this in the three-volume treatise titled Attachment and Loss, according to which

... the primary need of human beings - from infancy onward - is for supportive and rewarding relationships with other human beings. These relationships are the source of support and satisfaction, and the universal need for 'attachment' extends far beyond the need for sexual fulfilment. (Bowlby, 1969, cf. Storr, 2010, p. 27)

As Storr notes regarding the topic of community and communitiveness, despite its prominent position, an

...emphasis upon intimate interpersonal relationships as the touchstone of health and happiness is a comparatively recent phenomenon. Earlier generations would not have rated human relationships so highly; believing, perhaps, that the daily round, the common task, should furnish all we need to ask; or, alternatively, being too preoccupied with merely keeping alive and earning a living to have much time to devote to the subtleties of personal relations. (Storr, 2010, p. 17; idem, 2005, 1)

According to Ernest Gellner, whose authority is invoked by Storr,

...our present preoccupation with, and anxiety about, human relationships has replaced former anxieties about the unpredictability and precariousness of the 
natural world. ... In modern affluent societies - as Gellner claims - most of us are protected from disease, poverty, hunger, and natural catastrophes to an extent undreamed of by previous generations. (ibidem, p. 17; idem, 2005, p. 1)

The same is true of science. Beata Sierocka, for example, reminds us that 'Philosophy, and with it the humanities and social sciences, needed a surprisingly long time to incorporate the notions of community into their categorical structures' (Sierocka, 2007, p. 5). We can add that in this respect, both phenomena - solitude and communitiveness - shared the same fate. If we were to agree with Sierocka,

There were basically no projects until the German classics (especially until the Hegelian system) in which it would be even possible to anticipate the problem of community. Not to mention the possibility of estimating its significance, both in theoretical and practical terms. Philosophers needed even more time to conceptualize the sphere of linguistic communication processes, and especially to notice that it is in this area that the specificity of human existence and human knowledge is being constituted. (ibidem, p. 5)

This fixation on community, if I can put it this way, is regarded by many authors as dangerous. Plessner (2008, p. 27) says straightforwardly: 'In the conscious abandonment of the right to maintain distance between people by following the ideal of sinking into an expanding network of organic ties, man is threatened' (transl. A. Wójtowicz).

\section{Vita mixta: The consonance of solitude and communitiveness}

The tendency, characteristic of human philosophy, social philosophy or political philosophy from the earliest days, to antagonise the concepts of solitude and communitiveness proved to be idle, inadequate, and often harmful. In recent times, the Quattrocento idea of vita mixta has been revived; which, while accepting the antagonism of solitude and communitiveness, at the same time indicates that they exist on the principle of coincidentia oppositorum. The fundamental message of Plessner's work - signalled by its very title, which suggests the need to accept the existence of and to respect the 'limits of community' - is summarised in a very meaningful observation: 
It is not a matter of rejecting the law of the community of life, its nobility and beauty. It is a matter of rejecting its recognition as the only worthy form of human coexistence; it is not a matter of rejecting communio, but of rejecting communio as the only principle, rejecting communism as a way of life, rejecting radicalism of the community. (Plessner, 2008, p. 45)

In the field of psychoanalysis, Plessner is supported by the aforementioned Anthony Storr. As a guiding thought of his dissertation, the latter also employs the observation that the phenomena of solitude and communitiveness should be viewed as complementary, even though they are contradictory, and not - as they hitherto functioned - alternative options (Storr, 2010, p. 13). Such a move, in Storr's opinion, is to rehabilitate and enhance the value of solitude as a place for an individual's creative and personal development, and perhaps even as an important and useful method in the psychotherapeutic process. As he states:

Love and friendship are, of course, a significant part of what makes life worthwhile. But they are not the only source of happiness. ... Many ordinary interests, and the majority of creative pursuits involving real originality, continue without involving relationships. It seems to me that what goes on in the human being when he is by himself is as important as what happens in his interactions with other people. (ibidem, p. 14)

And finally, almost expressing the credo of the thesis as the dialectic tension between solitude and communitiveness, Storr concludes: 'Two opposing drives operate throughout our life: the drive for companionship, love, and everything else, and the drive toward being independent, separate, and autonomous' (ibidem, p. 14).

\section{Vita paradoxa: the unsocial sociability}

Storr's remark explicates, in fact, the important content of an idea that has accompanied the philosophy of solitude from its very beginning, albeit not developed for many centuries - and which, following Kant's famous expression, recognises the 'unsocial sociability of people' [die ungesellige Geselligkeit der Menschen] (Kant, 2005a, p. 34; cf. also: Plessner, 1988, pp. 286-298). This idea expresses, in the most spectacular way, the natural dialectical coupling between the phenomena of solitude and communitive- 
ness, here referred to as 'unsociability' and 'sociability'. In the Metaphysical Elements of the Theory of Virtue (Metaphysische Anfangsgründe der Tugendlehre, 1797), the philosopher from Königsberg, while clarifying his concept, laconically states that man is a creature meant for a social life (although at the same time an unsociable one) (Kant, 2005b, § 47, p. 151). Włodzimierz Galewicz explains this 'paradoxical property of humans' (as he calls it, after Kant) (ibidem, $\S 47$, p. 151, f.n. 360) with the condition where the 'tendency to come together in society' is balanced by 'resistance which constantly threatens to break this society up' (ibidem, $\S 47$, p. 151, f.n. 360 ). The author of the Metaphysics of Virtue illustrates this tension with an example of a powerful 'need to confide in others (even without any further purpose)' (ibidem, p. 152), when confronted with a fear 'which others could experience because of the thoughts revealed to them' (ibidem, p. 152). This fear has a limiting and preventive character. It is so powerful that it forces us to 'hide a significant part of our judgements (especially about other people)' (ibidem, p. 152).

[Man] would be happy to talk to someone about what he thinks about the people with whom he interacts, about government, religion, etc., but he cannot assume such a risk: partly because the other, who cautiously keeps his judgment to himself, could use his confessions to his detriment, and partly because, when it comes to revealing his own mistakes, the other could keep his own in secret, so that he himself would lose his respect, if he was to sincerely reveal himself before him [transl. A. W.]. (ibidem, p. 152)

This very legible, yet isolated and prosaic example of the occurrence of 'unsocial sociability' captures one of the important aspects of the dialectics of solitude and communitiveness - and, in a wider perspective, of the dialectical character of human existence. Namely, it is an ontologically sound relation between the desire for openness (being open to others) and the need to partially or completely close oneself to others. On the other hand, the case of 'unsocial sociability' illustrates the ethically important coincidence between sincerity in behaviour and the attitude towards others. Paradoxically, however, because of the others, and only indirectly due to oneself, the case of 'unsocial sociability' demands the use of numerous restraints and camouflages; whereas one would like to abandon them completely, or at least partially. Incidentally, we are dealing here with an interesting moral paradox - to use Saul Smilansky's expression (2009). It is the paradox of the partial or complete incompatibility of our moral expectations (claims) with the circum- 
stances with which we are confronted. For, on the one hand, we were ready to show sincerity to others; while on the other hand, fearing (unfortunately, often fully justifiably) the insincerity that they could externalise towards us, we restrain ourselves from a surge of sincerity (against ourselves - but for our own benefit) by becoming an open or a disguised hypocrite. Generally, however, our action is seasoned with a mixture of both - i.e. the community-forming sincerity, and also withdrawal into silence, pretence, lying or perversity, which condemns us to one or another kind of solitude. We agree as is noted, for example, by Leszek Kołakowski (2005, pp. 29-35) - that in interpersonal relations, despite a fairly widespread acceptance of the requirement of truthfulness, there is a far-reaching acquiescence towards behaviours which are more or less contradictory to it. The paradoxicality of this situation is enhanced by the fact that the claim of sincerity on both sides collides with mutual suspicion of insincerity. Thus, moral activity often boils down to seeking a tolerable balance between the indicated approaches - although there are people who do not recognise such or any other moral compromises, and advocate either maximum sincerity or ostentation in relations with others.

In the context of the main subject of the article, it is worth noting the simple yet significant relationship between solitude and communitiveness on the one hand, and sincerity and ostensibility on the other. Sincerity (at least at the level of intentions) is conducive to building a community through acquiring one of its most important building blocks, i.e. confidence; at the same time (at the level of actual social interactions) its excess is perceived as detrimental to the sustainability of the community. In such a case, sincerity, giving way to insincerity, becomes a cause of loneliness (a sense of seclusion or alienation), while insincerity in turn becomes a building material for the community. As the first ancient texts of philosophers interested in the problem of solitude demonstrate, solitude acts as an ally and an enclave of sincerity, while social life in genere offers more concession and encouragement for 'façade' behaviour based on insincerity.

The generalisation of this observation is connected with the third aspect of 'unsocial sociability', which has anthropological importance: i.e. the struggle between the authenticity and inauthenticity of human life. This is an extremely intriguing and wide-ranging subject, which deserves to be treated separately. Here we will confine ourselves only to reflecting on its importance for the philosophy of solitude; while at the same time pointing out that in general - especially in the case of its individualistic orientation, concentrating within itself an ontoexistential, contemplative and libertal interpretation of solitude - authenticity is associated in this aspect with loneliness. 
Communitiveness, in turn, is seen as a morally questionable (respective) tendency, which is an expression of human mediocrity, immaturity, dependence, unoriginality, schematism, uncritical imitation, conformist servitude, appearances, and finally, primitively understood sociability; it is motivated by the inability to confront the challenge of solitude, and the related isolation, silence and self-reflection that deeply penetrate our self-awareness and 'good' (albeit usually faked) disposition.

The Kantian dialectic of love and respect, for which the philosopher seeks - as he puts it himself - a 'harmonious balance' (Kant, 2005b, § 46, p. 149), is very much in harmony with the dialectic of solitude and communitiveness in the sphere of moral references. He explains it with the possibility of treating love as an 'attraction', and respect as a 'repulsion' between the parties involved; 'and while the principle of love compels [friends] to get closer to each other, the principle of respect compels them to keep an adequate distance from each other' (Kant, 2005b, p. 150). All this is done to avoid, even in the greatest friendship, such a degree of intimacy that strains or violates the principle of respect, making the whole relationship - at best merely a 'social form' (ibidem, p. 150).

Hence, it follows that the community-forming principle of love, contrary to the common, stereotypical beliefs - and in order to achieve the desired harmony between them - needs to be balanced by a proportional application of the principle of respect. This principle correlates with solitude - not, however, in the sense that it is a matter of having respect solely for oneself and contempt for others, but that it is only solitude. Such solitude can be even as prosaic as an ordinary temporary seclusion (caused, for example, by separation), which creates conditions conducive to gaining an adequate distance from a person or persons whom we owe not only love but also respect.

\section{References}

Bauman, Z. (2008). Wspólnota. W poszukiwaniu bezpieczeństwa w niepewnym świecie [Community. Seeking Safety in an Insecure World]. Transl. J. Margański. Kraków: Wydawnictwo Literackie.

Berdyaev, N. (2002). Rozważania o egzystencji. Filozofia samotności $i$ wspólnoty [Deliberations on Existence. Philosophy of Loneliness and Community]. Transl. H. Paprocki. Kęty: ANTYK.

Bowlby, J. (1969) Attachment and Loss. Vol. 1: Attachment. New York: Basic Books. 
Cacioppo, J. T. \& Patrick W. (2008). Loneliness: Human Nature and the Need for Social Connection. New York: W.W. Norton \& Company.

Dołęga, Z. (2003). Samotność młodzieży - analiza teoretyczna i studia empiryczne [Loneliness of the Young - Theoretical Analysis and Empirical Study]. Katowice: Wydawnictwo Uniwersytetu Śląskiego.

Domeracki, P. (2016). Rozstaje samotności. Studium filozoficzne [The Crossroads of Loneliness: A Philosophical Study]. Preface of B. L. Mijuskovic. Kraków: Nomos.

Domeracki, P. (2018). Horyzonty i perspektywy monoseologii. Filozoficzne studium samotności [Horizons and Perspectives of Monoseology. A Philosophical Study of Loneliness]. Torun: Wydawnictwo Naukowe UMK.

Domeracki, P. \& Tyburski, W. (eds.) (2006). Zrozumieć samotność. Studium interdyscyplinarne [To Understand Loneliness. An Interdisciplinary Study]. Toruń: Wydawnictwo UMK.

Dubas, E. (2000). Edukacja dorostych w sytuacji samotności i osamotnienia [Education of Adults Experiencing Loneliness and Solitude]. Łódź: Wydawnictwo UŁ.

Dybeł, K. (2009). Samotność w literaturze średniowiecznej Francji. Literatura narracyjna XII-XIII wieku [The Loneliness in the Medieval French Literature. Narrative literature of the 12th-13th centuries]. Kraków: Wydawnictwo UJ.

Grzybek, G. (2013). Samotność a kreacja [Loneliness and Creation]. Horyzonty Wychowania, 12(23), 7-10.

Hojat, M. \& Crandall, R. (eds.) (1987). Loneliness: Theory, Research and Applications. San Rafael, California: Select Press.

Howard, J. A. (1975). The Flesh-Colored Cage. The Impact of Man's Essential Aloneness on His Attitudes and Behavior. New York: Hawthorn Books, Inc. Publishers.

Kant, I. (2005a). Idea powszechnej historii w aspekcie kosmopolitycznym [Idea for a Universal History with a Cosmopolitan Purpose]. Transl. M. Żelazny. In idem, Rozprawy z filozofii historii [Treatises on the History of Philosophy]. Kęty: Antyk.

Kant, I. (2005b). Metafizyczne podstawy nauki o cnocie [Groundwork of the Metaphysics of Virtue]. Transl. W. Galewicz. Kęty: Antyk.

Kmiecik-Baran, K. (1988). Poczucie osamotnienia - charakterystyka zjawiska [A Feeling of Loneliness - A Characterization of the Phenomenon]. Przeglad Psychologiczny, 31(4), 1079-1098.

Kmiecik-Baran, K. (1992). Człowiek w sytuacjach samotności a poczucie osamotnienia [A Human in Situations of Solitude and the Feeling of Loneliness]. Zdrowie Psychiczne, 3-4, 95-107. 
Kmiecik-Baran, K. (1993). Osamotnienie w okresie dorastania [Loneliness in Adolescence]. Zdrowie Psychiczne, 1-2, 93-101.

Kołakowski, L. (2005). Mini wykłady o maxi sprawach [Mini-lectures on Maxi-issues]. Kraków: Znak. First series: O kłamstwie [On Deceit].

Kuklińska, K. L. (2013). Singlizm. Nowy styl życia w ponowoczesnym świecie [Singlism. A New Lifestyle in the Post-Modern World]. Warsaw: Collegium Civitas-Wydawnictwo Trio.

Lévinas, E. (1999). Czas i to, co inne [Time and the Other]. Transl. J. Migasiński. Warsaw: Wydawnictwo KR.

Lynch, J. J. (1977). The Broken Heart. The Medical Consequences of Loneliness in America. New York: Basic Books, Inc., Publishers.

Lynch, J. J. (1985). The Language of the Heart. The Body's Response to Human Dialogue. New York: Basic Books, Inc., Publishers.

Lynch, J. J. (2000). A Cry Unheard. New Insights into the Medical Consequences of Loneliness. Baltimore: Bancroft Press.

McGraw, J. G. (2010). Intimacy and Aloneness. A Multi-Volume Study in Philosophical Psychology. Vol. 1: Intimacy and Isolation. Amsterdam: Editions Rodopi.

McGraw, J. G. (2012). Intimacy and Aloneness. A Multi-Volume Study in Philosophical Psychology. Vol. 2: Personality Disorders and States of Aloneness. Amsterdam-New York: Editions Rodopi.

Mijuskovic, B. L. (2012). Loneliness in Philosophy, Psychology, and Literature. Bloomington: iUniverse, Inc.

Mijuskovic, B. L. (2015). Feeling Lonesome. The Philosophy and Psychology of Loneliness. Santa Barbara, California-Denver, Colorado: Praeger, An Imprint of ABC-CLIO, LLC.

Mijuskovic, B. L. (2019). Consciousness and Loneliness: Theoria and Praxis. Leiden-Boston: Brill Rodopi.

Moustakas, C. E. (1961). Loneliness. Englewood Cliffs, New York: Prentice-Hall.

Moustakas, C. E. (1972). Loneliness and Love. New York: Prentice-Hall.

Moustakas, C. E. (1974). Portraits of Loneliness and Love. New York: Prentice-Hall.

Moustakas, C. E. (1975). The Touch of Loneliness. New York: Prentice-Hall.

Mółka, J. (2012). Samotność i osamotnienie [Loneliness and Solitude]. Horyzonty Wychowania, 11(22), 17-34.

Pawłowska, R. \& Jundziłł, E. (2000, 2006). Pedagogika człowieka samotnego [Pedagogy of a Lonely Human]. Gdańsk: Gdańska Wyższa Szkoła Humanistyczna.

Peplau, L. A. \& Perlman, D. (1982). Loneliness: A Sourcebook of Current Theory, Research and Therapy. New York: John Wiley-Interscience. 
Plessner, H. (1988). Pytanie o conditio humana. Wybór pism [The Question of Conditio Humana. Selected Writings]. Transl. M. Łukasiewicz, Z. Krasnodębski, A. Załuska. Warsaw: PIW.

Plessner, H. (2008). Granice wspólnoty. Krytyka radykalizmu spolecznego [The Limits of Community: a Critique of Social Radicalism]. Transl. J. Merecki. Warsaw: Oficyna Naukowa S.c.

Ricoeur, P. (1989). Hermeneutyczna funkcja dystansu [The Hermeneutical Function of Distanciation]. In idem, Język, tekst, interpretacja. Wybór pism [Language, Text, Interpretation. Selection of Writings]. Transl. P. Graff \& K. Rosner. Warsaw: PIW.

Seneca, L. A. (1989). O pokoju ducha [Of Peace of Mind]. In idem, Dialogi [Dialogues]. Transl. L. Joachimowicz. Warsaw: Pax.

Sierocka, B. (2007). Wspólnota komunikacyjna $w$ teorii i praktyce [Communication Community in Theory and Practice]. Wrocław: Oficyna Wydawnicza ATUT, Wrocławskie Wydawnictwo Oświatowe.

Smilansky, S. (2009). 10 moralnych paradoksów [10 Moral Paradoxes]. Transl. W. Kostrzewski. Kraków: WAM.

Sobstyl, K. (2013). Samotność i jej obrazy w języku [Loneliness and Its Images in the Language]. Lublin: Wydawnictwo UMCS.

Stern, J. (2012). Loneliness and Solitude in Education. How to Value Individuality and Create an Enstatic School. Pieterlen: Peter Lang AG, Internationaler Verlag der Wissenschaften.

Storr, A. (2010). Samotność: powrót do jaźni [Solitude: a Return to the Self]. Transl. J. Prokopiuk \& P. J. Sieradzan. Warsaw: Wydawnictwo W.A.B.

Storr, A. (2005). Solitude: a Return to the Self. New York: Free Press.

Szeliga, D. \& Zółkiewska, E. D. (eds.) (2010). Motywy samotności $i$ wspólnoty $w$ dawnych literaturach romańskich (Średniowiecze - Oświecenie) [Motifs of Solitude and Community in Old Romanesque Literatures (Middle Ages - Enlightenment)]. Warsaw: Wydawnictwa Uniwersytetu Warszawskiego.

Turkle, S. (2013). Samotni razem. Dlaczego oczekujemy więcej od zdobyczy techniki, a mniej od siebie nawzajem [Alone together. Why we Expect More from Technology and Less from Each Other]. Transl. M. Cierpisz. Kraków: Wydawnictwo UJ.

Twardowska-Rajewska, J. (ed.) (2005). Przeciw samotności [Against lonliness]. Poznań: Wydawnictwo Naukowe UAM. 